\title{
SOSIALISASI GERAKAN SOCIAL DISTANCING DAN ENHANCED HYGIENE DALAM RANGKA PENCEGAHAN DAN PENGENDALIAN PENYEBARAN COVID-19 DI KELURAHAN LALODATI, KOTA KENDARI, PROVINSI SULAWESI TENGGARA
}

${ }^{1}$ Fifi Nirmala G, ${ }^{2}$ Al Jalali Muhammad, ${ }^{3}$ Fithria, ${ }^{4}$ Aslan Dita

${ }^{1234}$ Universitas Halu Oleo

Email: aljalalimuhammad17@gmail.com

\section{RINGKASAN}

COVID-19 merupakan penyakit yang belum lama tepatnya pada bulan Desember 2019 muncul dan mewabah. Penyakit ini pertama kali ditemukan di China yang belum diketahui secara pasti asal mulanya tepatnya di Wuhan. Penularannya dapat terjadi secara lansung maupun tidak lansung. Oleh karena itu penting untuk melakukan social distancing dan enhanced hygiene dengan siapapun karena waktu inkubasi virus ini terjadi selama 14 hari. Upaya-upaya ini dilakukan sebagai bentuk pengurangan transmisi. Dengan social distancing orang yang sehat dan sakit tidak bersentuhan sehingga peluang untuk penyebaran COVID19 semakin kecil. Begitu pula dengan enhanced hygiene, misalnya dengan rajin mencuci tangan. Kita sering kali tidak sadar telah menyentuh permukaan benda-benda yang tidak bisa dipastikan apakah steril dari SARS-CoV-2 atau tidak. Kita juga sering kali secara tidak sadar menyentuh daerah-daerah yang menjadi jalan masuk SARS-CoV-2 olehnya penting untuk rajin mencuci tangan menggunakan sabun selama 20 hingga 30 detik secara baik dan benar. COVID-19 yang aawalnya hanya menyerang penduduk Wuhan kini telah sampai di Indonesia. penularannya cukup cepat dengan jumlah peningkatan pasien yang sangat signifikan serta angka kematian yang tinggi. Hal ini bisa jadi disebabkan karena sebagian warga Indonesia belum mengetahui upaya pencegahan serta penanganan COVID-19. Kota Kendari pun terimbas COVID-19. Tujuan dari kegiatan ini adalah untuk memberikan pengetahuan kepada masyarakat upaya yang bisa dilakukan untuk mencegah serta melakukan pengendalian terhadap penyebaran COVID-19 mengingat angka mortalitas Indonesia yang tinggi. Hasil dari kegiatan ini sangatlah positif, secara umum dari setiap kegiatan yang dilakukan, masyarakat memberikan respon yang sangat positif, yaitu masyarakat mempraktekkan hasil sosialisasi serta memberikan petanyaan yang menurut mereka masih belum jelas seperti aturan social distancing serta enhanced hygiene.

\section{Kata kunci: Social Distancing; Enhanced Hygiene; Pencegahan; Pengendalian; Covid-19}

\section{A. Analisis Situasi}

Dunia Internasional dikejutkan dengan penemuan pneumonia jenis baru pada bulan Desember 2019. Pneumonia jenis baru ini ditemukan di Wuhan, China. Penyakit yang sangat menggemparkan ini ketika baru ditemukan, disebut dengan 2019-nCoV atau novel coronavirus yang disebabkan oleh virus yang masih satu kelompok dengan SARS (Severe 
Accute Respiratory Syndrome) dan MERS (Middle East Respiratory Syndrome). Penyakit ini dapat menimbulkan gejala mulai dari flu atau yang lebih berat menyerang saluran pernafasan. Penyakit 2019-nCoV ini belum pernah teridentifikasi menyerang manusia sebelumnya. Beberapa bulan setelah diidentifikasi, WHO secara resmi mengumumkan nama dari pneumonia jenis baru ini dengan nama COVID-19 yang disebabkan oleh SARSCoV-2 (Severe Accute Respiratory Syndrome Coronavirus 2) [1].

Sekitar 44 kasus terdeteksi penderita COVID-19 pada mulanya di bulan Desember 2019 di Wuhan, China. Tidak berselang lama, COVID-19 sudah menyebar ke berbagai penjuru dunia. Penyebaran penyakit COVID-19 yang sangat cepat ini menjadi salah satu alasan pentepannya sebagai pandemi. Oleh WHO pada tanggal 11 Maret 2020[2]. Pandemi merupakan epidemi yang terjadi melewati batas skala Internasional, umumnya mempengaruhi sejumlah besar orang [3].

Severe Acute Respiratory Syndrome Coronavirus-2 ini dapat menular dari manusia ke manusia, dari hewan ke manusia dan dari manusia ke hewan melalui transmisi. SARSCoV-2 dengan sangat mudah menyebar sehingga tidak menunggu waktu lama, virus ini telah menyebar di berbagai penjuru dunia, tak terkecuali di Indonesia [4]. COVID-19 pertama kali terdeteksi sampai di Indonesia melalui 2 laporan kasus pada tanggal 2 Maret 2020 [5]. Per 31 Maret 2020 telah terkonfirmasi jumlah kasus COVID-19 sebanyak 1.528 dengan 136 kasus kematian [6]. Tingkat mortalitas tertinggi di Asia Tenggara diduduki oleh Indonesia dengan persentase 8,9\% [7]. Jumlah laporan kasus COVID-19 di seluruh dunia yang terkonfirmasi sebanyak 693.224 Kasus dengan 33.106 kasus kematian per 30 Maret 2020. Amerika menduduki peringkat pertama dengan jumlah kasus penambahan COVID-19 terbanyak, yaitu sebanyak 19.332 kasus serta Italia dengan jumlah kasus kematian terbanyak per harinya di seluruh dunia [4]. Dari semua data kasus COVID-19 yang disajikan oleh WHO menjadi indikator bahwa SARS-CoV-2 sangatlah mudah menyebar.

SARS-CoV-2 merupakan virus yang bersifat zoonotik, yaitu virus yang bertransmisi dari hewan ke manusia. SARS-CoV-2 bersirkulasi pada beberapa jenis hewan, yaitu unta, kucing, kelelawar dan musang. Sebelumnya, telah terjadi wabah Coronavirus yang 
disebabkan oleh SARS-CoV yang diketahui berasal dari kelelawar. Wabah ini terjadi pada tahun 2002, yang berawal di Guangdong, CHIna hingga tersebar di 29 negara di Dunia dengan $10 \%$ kematian serta teridentifikasi sekitar 8000 kasus. Kemudian, selang 10 tahun kemudian, terjadi lagi wabah yang hampir sama, yaitu pada tahun 2012 yang bertempat di Arab Saudi terjadi wabah Coronavirus yang disebabkan oleh MERS-CoV (Middle East Respiratory Syndrome Coronavirus). Wabah ini tersebar hingga di 27 negara dengan sekitar 2000 jumlah kasus dan $37 \%$ kematian.

Seiring dengan merebaknya COVID-19, banyak berita palsu pula yang bermunculan. Misalnya, bawang putih dapat mencegah penularan COVID-19. Nyatanya belum ada penelitian secara ilmiah terkait berita ini. Selain itu, ada juga berita yang menyebutkan bahwa alkohol $70 \%$ dapat mematikan SARS-CoV-2 jika dikonsumsi. Nyata, alkohol $70 \%$ memang digunakan sebagai desinfektan untuk permukaan benda yang tercemar SARSCoV-2 tetapi tidak bisa dikonsumsi lansung oleh manusia sebab dapat menyebabkan kematian. Ada juga yang menyebutkan bahwa COVID-19 dapat menular pada manusia melalui paket yang dikirim dari China. Faktanya, berdasarkan hasil penelitian yang dilakukan oleh [8] di Amsterdam bahwa, SARS-CoV-2 dapat bertahan hidup di permukaan benda yang terbuat dari plastik dan stainless stee/ selama lebih dari 72 jam, pada tembaga 4 jam dan pada kardus 24 jam [9]. Ada juga kabar yang menyatakan bahwa COVID-19 sangatlah mematikan sehingga kita perlu panik. Faktanya, hasil analisis data tentang Coronavirus menunjukan bahwa COVID-19 memiliki angka kematian sebesar 2\% - 3\%. Angka ini diketahui jauh lebih rendah dibandingkan wabah lain yang sejenis (SARS, MERS, Swine Flu) sehingga tidak perlu panik, tetapi tetap harus waspada.

Gejala dan tanda seorang terpapar COVID-19, yaitu terdapat dua jenis gejala, gejala utama dan gejala penyerta. Gejala utama meliputi, demam/meriang, batuk, nyeri tenggorokan dan sulit bernafas/sesak. Sedangkan gejala penyerta seperti diare, nyeri kepala dan pegal-pegal. Terdapat dua kategori orang yang harus diketahui, yaitu pasien dalam pengawasan dan orang dalam pemantauan. Pasien dalam pengawasan memiliki gejala demam/riwayat demam, batuk/pilek/nyeri tenggorokan dan pneumonia ringan hingga berat. Faktor risikonya, memiliki riwayat perjalanan dari negara yang terpapar 
COVID-19 dalam 14 hari terakhir, memiliki demam yang lebih dari $38^{\circ} \mathrm{C}$ serta memiliki riwayat atau kontak dengan hewan penular COVID-19. Orang dengan ciri seperti ini harus segera di bawa ke rumah sakit rujukan COVID-19 untuk diisolasi. Adapun untuk orang dalam pengawasan, memiliki gejala demam/riwayat demam dan batuk/pilek/nyeri tenggorokan. Faktor risikonya, yaitu memiliki riwayat perjalanan dari negara yang terpapar COVID-19 dalam 14 hari terakhir. Jika ditemui orang dengan ciri-ciri tersebut, maka tidak perlu panik [10].

Diketahui bahwa, saat ini sumber transmisi utama adalah dari manusia ke manusia. Akibatnya, penyebaran COVID-19 menjadi lebih mudah dan cepat. Penyebaran SARSCoV-2 dari pasien ke manusia sehat adalah melalui droplet yang keluar saat batuk atau bersin, kontak dekat seperti menyentuh dan jabat tangan, menyentuh objek atau permukaan yang terkontaminasi virus, kemudian menyetuh mulut, hidung atau mata sebelum mencuci tangan dengan sabun dan kontaminasi feses (sangat jarang)[11].

Berdasarkan penjelasan di atas, maka penting untuk mengetahui cara pencegahan serta pengendalian penyebaran COVID-19 mengingat penularannya yang sangat mudah dan cepat. Belum ada vaksin untuk mencegah human coronavirus, tetapi transimi dapat dikurangi dengan mencuci tangan secara rutin dengan sabun dan air atau handsanitizer, terutama setelah batuk, bersih atau setelah menggunakan toilet, sebelum menyiapkan makanan dan setelah kontak dengan pasien atau barang pribadi miliki pasien COVID-19. Selain itu, transmisi juga dapat dikuringi dengan mengurangi menyentuh mata, hidung dan mulut sebelum mencuci tangan. Kemudian, dengan penggunaan masker juga merupakan salah satu cara pengurangan transmisi SARS-CoV-2 serta menghindari kontak dengan pasien COVID-19 baik secara lansung maupun tidak lansung [12]. Secara garis besar, upaya pengurangan transmisi SARS-CoV-2 yaitu dengan melakukan gerakan social distancing dan enhanced hygiene dapat menjadi solusi pencegahan serta pengendalian penyebaran COVID-19. Social distancing merupakan sebuah metode untuk meminimalisasi interaksi atau kerumunan dan mencegah penularan COVID-19 dengan cara menjaga jarak sejauh dua meter antar orang dengan kata lain menghindari kerumunan [13]. Dr. Erni menyatakan bahwa, ada sebuah penelitian yang menunjukkan, 
virus influenza dapat menular ke banyak orang melalui rantai penularan yang begitu panjang. Artinya, satu orang sakit bisa menularkan ke dua orang sehat atau lebih, dan masing-masing orang yang terinfeksi juga akan menularkan ke lebih banyak orang. Sehingga, work from home atau social distancing dan berdiam diri di rumah sangat penting untuk memutus rantai penularan [14].

Selain social distancing, enhanced hygiene juga dipercaya dapat menjadi salah satu cara sebagai pencegah dan pengendali penyebaran COVID-19. Selama masa pandemi COVID19, peningkatan kebersihan oleh setiap individu sangat perlu diperhatikan serta dilakukan. Enhanced hygiene meliputi rajin mencuci tangan sesuai dengan anjuran yang telah dikeluarkan oleh para dokter dan menerapkan etika bersin dan batuk. Adapun tata cara mencuci tangan yang baik dan benar sesuai anjuran, yaitu melakukan cuci tangan selama 20 hingga 30 detik yang diawali dengan membasahi kedua tangan menggunakan air yang mengalir kemudian memakai sabun, menggosokkan kedua telapak tangan, menggosok setiap punggung tangan dan sela-sela jari serta menangkupkan kedua tangan dan menggosok pinggir-pinggir jari. Adapun etika batuk dan bersin, yaitu dengan menutup mulut dan hidung menggunakan siku ketika batuk ataupun bersih dan kemudian mencuci tangan.

Kota Kendari merupakan salah satu kota yang terdapat di Indonesia, yang juga terimbas COVID-19. Untuk saat ini, terdapat beberapa kasus positif COVID-19 di Kota Kendari yang tersebar di beberapa kelurahan. Lalodati merupakan salah satu kelurahan yang berada di Kota Kendari, namun Lalodati juga merupakan salah satu kelurahan yang tidak memiliki atau masih belum memiliki pasien positif COVID-19. Jika dilihat pada peta, Lalodati merupakan daerah yang terletak di jalur antar provinsi. Diketahu bersama bahwa jalur provinsi yang tentunya berbagai jenis orang dari luar maupun dalam kota akan melewatinya bahkan singgah. Hal ini menyebabkan Lalodati dikhawatirkan begitu rawan sebagai daerah calon korban infeksi SARS-CoV-2. Berdasarkan semua penjelasan tersebut perlu dilakukan Sosialisasi Gerakan Social Distancing dan Enhanced Hygine dalam Rangka Pencegahan dan Pengendalian Penyebaran/Penularan COVID-19 di Kelurahan Lalodati, Kecamatan Puuwatu, Kota Kendari, Provinsi Sulawesi Tenggara. 


\section{Metode Pelaksanaan}

Sosialisasi Gerakan Social Distancing dan Enhanced Hygine dalam Rangka Pencegahan dan Pengendalian Penyebaran/Penularan COVID-19 di Kelurahan Lalodati, Kecamatan Puuwatu, Kota Kendari, Provinsi Sulawesi Tenggara. dilaksanakan pada bulan Mei-Juni 2020 bertempat di Kelurahan Lalodati, Kecamatan Nambo, Kota Kendari, Provinsi Sulawesi Tenggara. Beberapa kegiatan yang dilakukan pada program Sosialisasi Gerakan Social Distancing dan Enhanced Hygiene dalam Rangka Pencegahan dan Pengendalian Penyebaran/Penularan COVID-19 adalah sebagai berikut:

1. Sosialisasi mengenai Severe Acure Respiratory Syndrome Coronasvirus 2 (SARS-CoV2) atau Coronavirus desease 2019 (Covid-19) kepada mahasiswa peserta KKNTematik. Langkah pertama adalah memberikan pemahaman kepada mahasiswa peserta KKN-Tematik.

2. Mahasiswa peserta KKN-Tematik diberikan tugas untuk membuat video edukasi terkait COVID-19, mulai dari proses dan cara penularan, gejala, serta cara penanganan yang tepat yaitu dengan social distancing dan penerapan psikologi positif saat pertama kali merasa terkena gejala COVID-19, mengingat penyebaran COVID-19 yang semakin meluas, sehingga mahasiswa dilarang untuk turun lansung ke lapangan.

3. Mahasiswa peserta KKN-Tematik diberikan tugas untuk membuat baliho dan poster serta pamflet yang menarik minat baca masyarakat di Kelurahan Lalodati tentang bahaya COVID-19 serta semua gejala dan cara penyebarannya serta penanganannya.

4. Tim dosen beserta teknisi membagiakan pamflet dari pintu ke pintu kepada masyarakat kelurahan Tondongeu.

5. Tim dosen beserta teknisi membagikan masker dan video edukasi terkait COVID-19 secara lansung kepada masyarakat kelurahan Lalodati yang sesuai dengan protokol kesehatan yang telah dikeluarkan oleh pemerintah.

Target pada kegiatan Sosialisasi Gerakan Social Distancing dan Enhanced Hygiene dalam Rangka Pengendalian dan Pencegahan Penyebaran/Penularan COVID-19 adalah masyarakat kelurahan Lalodati. Lalodati dipilih karena terletak di lokasi strategis yaitu 
jalur yang menghubungkan provinsi Sulawesi Tenggara dengan Provinsi Sulawesi Tengah. Dengan keadaan ini, maka peluang untuk masyarakat di Kelurahan Lalodati terjangkit COVID-19 cukup besar, itulah sebabnya masyarakat kelurahan Tondongeu dipilih sebagai target dalam kegiatan ini.

Indikator keberhasilan pada kegiatan kali ini yaitu masyarakat dapat memahami COVID19 secara umum, pencegahan serta pengendalinanya. Adapun metode yang dilakukan untuk mengukur ketercapaian keberhasilan indikator, yaitu dengan melihat data kesehatan dari puskesmas setempat masyarakat di kelurahan Tondongeu sejak awal pelaksanaan kegiatan hingga selesai serta dari aktivitas sehari-hari masyarakat kelurahan Lalodati dalam upaya pencegahan penularan COVID-19 seperti rajin mencuci tangan, menggunakan masker dan lain sebagainya.

\section{Hasil dan Pembahasan}

Hasil dari kegiatan Sosialisasi Gerakan Social Distancing dan Penerapan Metode Psikologi Positif Enhanced Hygiene, yaitu bertambahnya pengetahuan serta pemahaman masyarakat di Kelurahan Lalodati terhadap COVID-19 secara umum dan khusus serta masyarakat setidaknya mendapat satu buah masker setiap orang. Adapun hasil capaian dari kegiatan ini disajikan dalam bentuk tabel yang dapat dilihat di bawah ini.

Tabel 1. Hasil capaian Kegiatan Pengabdian Kepada Masyarakat

\begin{tabular}{|l|l|l|}
\hline No & Nama Kegiatan & Keterangan Kegiatan \\
\hline 1 & $\begin{array}{l}\text { Pemasangan } \\
\text { COVID-19 }\end{array}$ & $\begin{array}{l}\text { Pemasangan baliho terkait COVID-19 mulai dari } \\
\text { apa itu COVID-19, langkah-langkap } \\
\text { pencegahanyya serta cara penularannya yang } \\
\text { dilakukan oleh tim dosen serta teknisi. }\end{array}$ \\
\hline 2 & Pembagian Masker & $\begin{array}{l}\text { Pembagian masker yang dilakukan oleh teknisi } \\
\text { serta tenaga kesehatan setempat kepada setiap } \\
\text { warga kelurahan Tondongeu. }\end{array}$ \\
\hline 3 & Pembagian pamflet & $\begin{array}{l}\text { Pembagian pamflet yang dilakukan oleh teknisi } \\
\text { serta tenaga kesehatan setempat kepada setiap } \\
\text { warga kelurahan Tondongeu. }\end{array}$ \\
\hline
\end{tabular}




\begin{tabular}{|l|l|l|}
\hline 4 & Pembagian video & $\begin{array}{l}\text { Pembagian video tentang edukasi COVID-19 yang } \\
\text { disebarkan melalui media sosial dalam hal ini } \\
\text { whatsapp. }\end{array}$ \\
\hline
\end{tabular}

Kegiatan Pengabdian Kepada Masyarakat terkait COVID-19 dilakukan mengingat banyaknya jumlah peningkatan pasien COVID-19 di Indonesia. Diharapkan melalui kegiatan sosialisasi ini, masyarakat kelurahan Lalodati lebih memahami upaya yang harus dilakukan terhadap pencegahan maupun penaganan COVID-19. Diantara banyaknya cara, pada sosialisasi ini kami menawarkan secara garis besarnya, yaitu social distancing dan enhanced hygiene. Kami mengangkat tema ini sebab sangat penting disaat pandemi seperti ini. Masyarakat seringkali tidak mengetahui aturan-aturan yang harus dilakukan. Contohnya masih banyak kerumunan, masih banyak pula orang yang makan tanpa cuci tangan serta aksi yang sejenis. Dengan dilaksanakannya kegiatan ini, masyarakat telah memperoleh ilmu baru yang belum diketahui tentang COVID-19 walaupun sosialisasi dilakukan secara tidak lansung. Dilakukan sosialisasi secara tidak lansung mengingat tingginya angka penderita COVID-19 belakangan. Sehingga selain melakukan upaya sosialisasi, tim dosen juga mempraktekkannya yang menyebabkan tidak dilakukannya sosialisasi secara lansung, melainkan melalui media-media, yaitu pamflet, baliho, dan video. Dalam kegiatan sosialisasi ini, dilakukan beberapa tahapan.

Tahap awal dilakukan oleh tim dosen, yaitu melakukan pemasangan baliho di sejumlah RT di kelurahan Lalodati. sebelum dilakukan pemasangan baliho, tim dosen telah lebih awal melakukan komunikasi dengan Lurah di Kelurahan Lalodati guna kelancaran kegiatan sosialisasi pengabidan kepada masyarakat. Baliho yang dibuat tersebut merupakan karya mahasiswa yang diseleksi oleh tim dosen serta digunakan yang dianggap paling bagus. Jadi sebenarnya yang paling awal adalah dengan memberikan pemahaman kepada mahasiswa terkait COVID-19 ini. Baliho yang dibuat memuat COVID19, pencegahan, penularan serta penanggulangan COVID-19. Baliho yang dibuat diusahakan semenarik mungkin sehingga meningkatkan minat baca para masyarakat. Jika masyarakat saja sudah malas membacanya, maka sosialisasi ini tidak akan efektif. Olehnya sangat penting membuat suatu media baca yang menarik. 

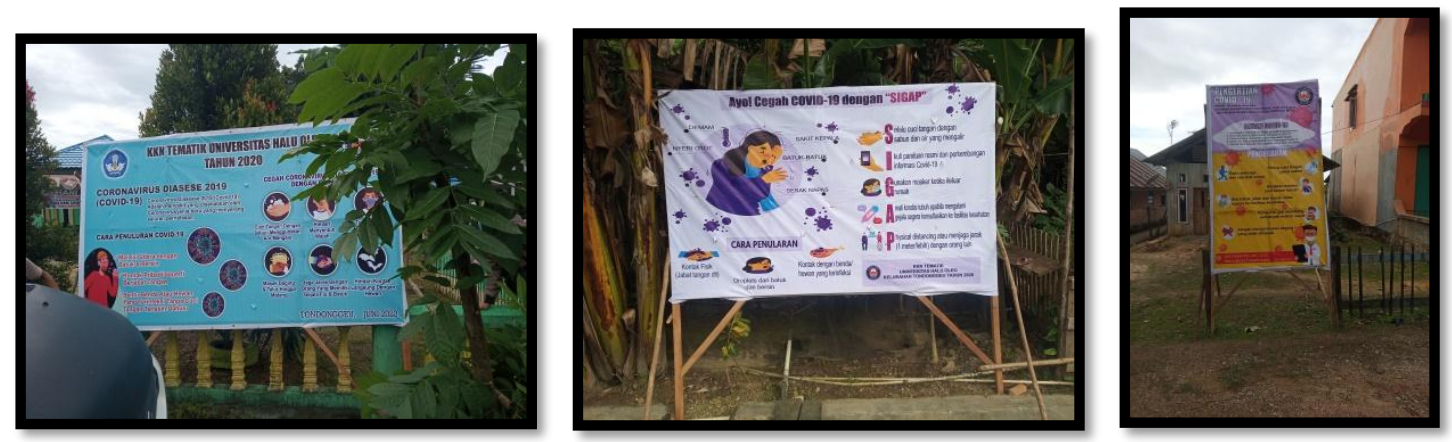

Gambar 1. Baliho yang dibuat mahasiswa KKN Tematik untuk masyarakat kelurahan Tondongeu

Selain pemasangan baliho di beberapa RT di kelurahan Lalodati, dilakukan juga pembagian Pamflet yang isinya memuat edukasi terkait COVID-19 dan new normal. Setiap kegiatan yang dilakukan selalu memiliki tujuan walaupun kegiatannya hampir sama. Adapun pembagian pamflet dilakukan agar masyarakat yang mungkin belum sempat membaca baliho karena takut keluar rumah atau tidak memperhatikan sekitaran jalan yang terdapat baliho COVID-19 bisa memperoleh informasi melalui pamflet-pamflet tersebut. Pembagian pamflet dilakukan oleh dari pintu rumah yang satu ke pintu rumah yang lainnya. Selain itu dilakukan juga pemasanagan poster-poster kecil di tempat umum yang sering dikunjungi oleh masyarakat. Semua kegiatan yang dilakukan berdasarkan pertimbangan yang sangat matang. Alasan pembagian pamflet dari pintu ke pintu adalah agar tidak terjadi kerumunan mengingat pentingnya social distancing saat masa pandemi seperti sekarang ini serta untuk memberi contoh juga kepada masyarakat sekitar. Salah satu keuntungan dari pembagian pamflet ke rumah-rumah adalah penerimanya ibu rumah tangga. Ibu rumah tangga merupakan anggota keluarga yang sangat peduli terhadap keadaan di dalam rumahnya sehingga, ketika dilakukan pembagian beberapa pertanyaan pun dilontarkan terkait COVID-19. Hal ini tentu sangat positif sebab upaya paling awal dalam pencegahan COVID-19 adalah dimulai dari dalam keluarga. 


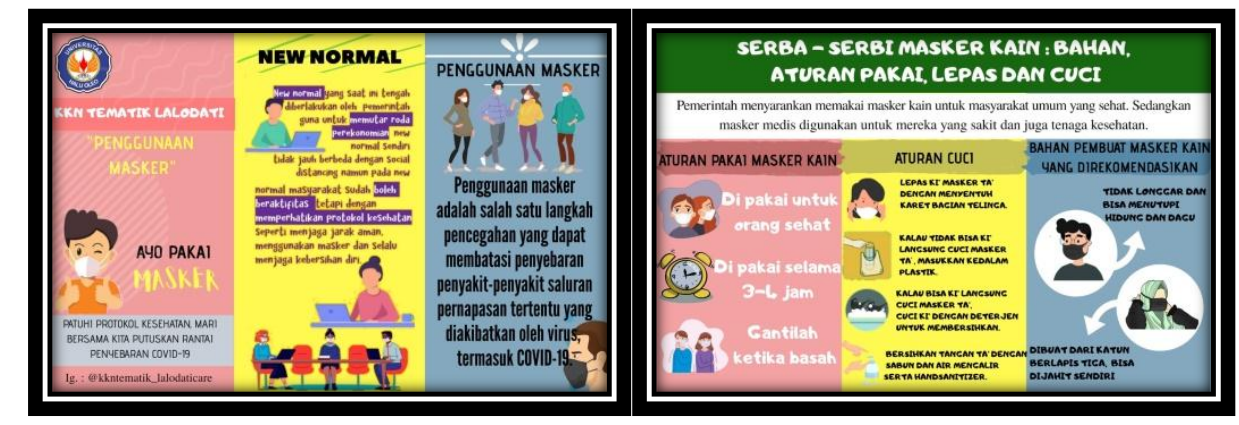

Gambar 2. Tampilan pamflet yang dibagikan kepada masyarakat di kelurahan Lalodati Tahap berikutnya dari pelaksanaan kegiatan Sosialisasi Gerakan Social Distancing dan Enhanced Hygiene dalam Rangka Pencegahan/Penularan COVID-19 di kelurahan Lalodati yaitu dengan membagikan video edukasi terkait COVID-19 yang memuat cara pencegahan, antisipasi serta cara hidup bersih dan sehat. Pada video tersebut, yang paling ditekankan adalah cara mencuci tangan yang baik dan benar mengingat selama ini sebagian besar masyarakat masih melakukan cuci tangan dengan cara yang belum benar. Cara mencuci tangan yang benar, yaitu dengan mencuci tangan pada air yang mengalir selama 20 hingga 30 detik dengan menggosok kedua punggung tangan, selasela jari, dan semua bagian tangan yang selama ini jarang diperhatikan ketika mencuci tangan. Mengapa cuci tangan ini sangat kami tekankan. Karena penyebaran COVID-19 secara tidak lansung ini sangat banyak terjadi. Masyarakat seringkali tidak sadar telah menyentuh permukaan benda yang telah disentuh oleh pasien COVID-19 sehingga di permukaan penda tersebut hidup SARS-CoV-2. Dilakukannya pembagian video ini adalah agar menambah pemahaman masyarakat terkait COVID-19 karena seringkali melalui tayangan orang akan lebih memahami maksud dan tujuan dari sebuah instruksi mengingat tim dosen tidak bisa turun lansung ke lapangan disebabkan pandemi COVID19. Video yang dibagikan dibuat khusus oleh mahasiswa dari Fakultas Kesehatan

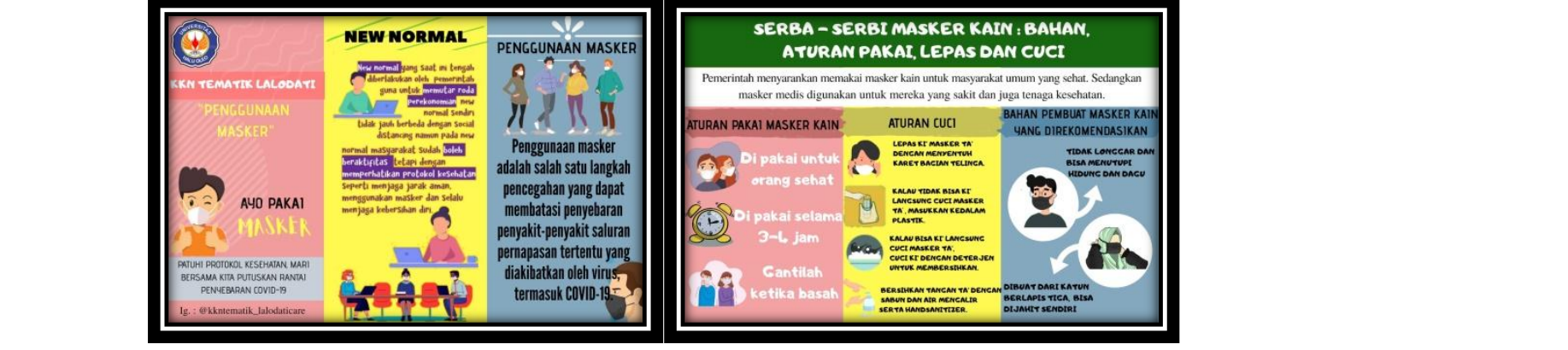
Masyarakat dan Fakultas MIPA yang sedang melaksanakan KKN Tematik. Video yang telah dibuat kemudian disebarluaskan melalui media sosial (Whatsapp). 


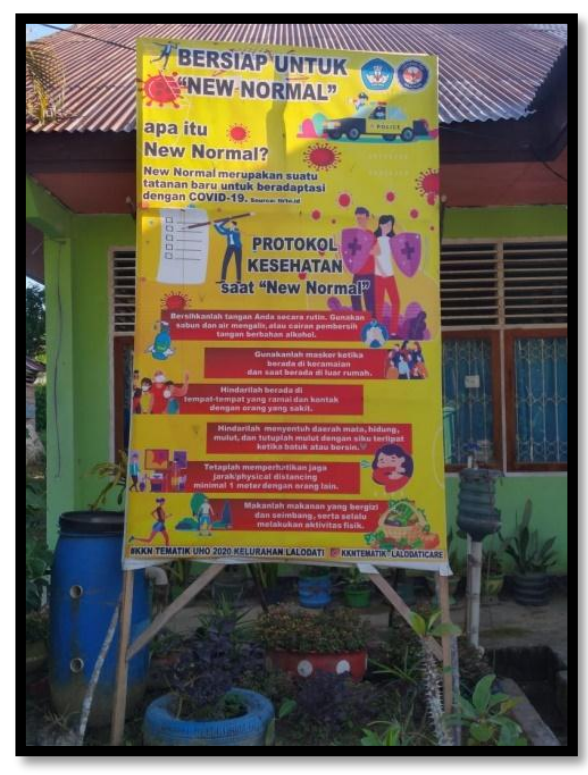

Gambar 3. Baliho yang dipasang di kelurahan Lalodati

Selain dilakukannya pembagian video edukasi terkait COVID-19, masyarakat kelurahan Lalodati juga juga dibagikan masker dengan harapan akan digunakan sebagai salah satu langkah dalam enhanced hygiene dalam pencegahan penularan COVID-19. Masker dibagikan oleh salah satu dosen, Lurah dan petugas kesehatan di kelurahan Lalodati. Semua usaha serta upaya yang dilakukan tim dosen serta peserta KKN Tematik UHO mendapat respon yang sangat positif oleh warga kelurahan Lalodati. Hasil akhir dari kegiatan ini yaitu masyarakat menerapkan social distancing yang dapat dilihat, biasanya di pinggir jalan ada kerumunan orang-orang. Namun, setelah sosialisasi dilakukan hampir tidak ada lagi kerumanan orang-orang. Selain itu, masyarakat ketika keluar rumah juga sudah menggunakan masker dari yang awalnya masih acuh tak acuh terhadap masker.

\section{Kesimpulan}

COVID-19 merupakan penyakit baru yang disebabkan oleh SARS-CoV-2 dan secara resmi oleh WHO telah diumumkan sebagai pandemi. COVID-19 bukanlah penyakit yang sangat mengerikan sehingga membuat masyarakat panik, tetapi harus tetap waspada. Banyak berita hoax yang bertebaran terkait COVID-19 olehnya penting untuk mensosialisasikan kepada masyarakat tentang COVID-19 agar masyarakat dapat mengetahui mana berita yang benar dan mana yang hoax. Dalam rangka pemberian informasi terkait COVID-19, telah dilakukan berbagai upaya, mulai dari pemasangan baliho di beberapa RT kelurahan 
Tondongeu, pembagian pamflet dari pintu ke pintu agar tidak terjadi kerumunan, pembagian masker serta pembagian video edukasi terkait COVID-19. Hasil dari semua upaya ini adalah respon positif dari masyarakat kelurahan Lalodati dengan mengikuti tata cara yang diberikan secara baik dan bersungguh-sungguh.

\section{Ucapan Terima Kasih}

Kami tim dosen yang melaksanakan Pengabdian kepada Masyarakat terkait kegiatan Sosialisasi Gerakan Social Distancing dan Penerapan Metode Psikologi Positif dalam Rangka Pencegahan dan Pengendalian Penyebaran COVID-19 di kelurahan Lalodati mengucapkan banyak terima kasih kepada UHO yang telah memberikan kesempatan kepada kami untuk dapat melaksanakan kegiatan kami, kemudian tidak lupa kami ucapkan terima kasih juga kepada lurah serta masyarakat kelurahan Lalodati yang sangat antusias serta memberi respon yang sangat positif dalam menerima materi walaupun tidak dilakukan secara lansung tetapi melalui berbagai media. Dan ucapan terima kasih juga kami ucapkan kepada para teknisi serta mahasiswa yang telah ikut serta dalam kegiatan yang bermanfaat ini.

\section{Daftar Pustaka}

[1] World Health Organization, 2019, Coronavirus. Retrieved from WorldHealth Organization.

[2] Widiyani, R. (2020). Latar Belakang Virus Corona, Perkembangan hingga Isu Terkini. Retrieved from detikNewshttps://news.detik.com/berita/d4943950/latar-belakangvirus-coronaperkembangan-hingga-isu-terkini.

[3] Wikipedia Indonesia, 2020, Pandemi, https://id.wikipedia.org/wiki/pandemi

[4] World Health Organization, 2020, Coronavirus Disease 2019 (COVID-19), Situation Report, WHO.

[5] World Health Organization, 2020, Situation Report. [6] World Health Organization, 2020, WHO Director General's Opening Remarks at the Media Briefing on COVID19.

[6] Kementeria Kesehatan Republik Indonesia , 2020, Info Infeksi Emerging Kementerian Kesehatan RI. 
[7] World Health Organization, 2020, Novel Coronavirus (2019-nCoV) Situation Report.

[8] van Doremalen N., Bushmaker T., Morris DH., Holdbrook MG., Gabmle A. Dan Williamson BN., 2020, Aerosol and Surface Stability of SARS-CoV-2 as Compared with SARS-CoV-1, N Eng J Med..

[9] Susilo, A., C. Martin R., Ceva W.P., Widayat D.S., Mira Y., Herikurniawan, Robert S., Gurmeet S., Leonard N., Erni J.N., Lie K.C., Alvina W., Edwin W., Bramantya W., Maradewi M., Firda A., Chyntia O.M.J. dan Evy Y., 2020, Coronavirus Disease 2019: Review of Current Literatures, Jurnal Penyakit Dalam Indonesia, 7 (1).

[10] Kementeria Kesehatan Republik Indonesia , 2020, Info Infeksi Emerging Kementerian Kesehatan RI.

[11] Han Y. Dan Yang H., 2020, The Transmition and Diagnosis of 2019 Novel Coronavirus Infection Disease (COVID-19), Med Virol Journal.

[12] Burhan, Erlina, 2020, Coronavirus Disease 2019 (COVID-19), Departemen Pulmonologi dan Ilmu Kedokteran Respirasi FKUI - RSUP Pershabatan, Satgas Waspada dan Siaga COVID-19 PB IDI.

[13] Aslam, F., 2020, COVID-19 and Importance of Social Distancing, University of Woverhampton.

[14] Yus Mei Sawitri, 2020, Pentingnya Social Distancing untuk Menghindari Infeksi Virus COVID-19, Liputan 6. 